\title{
Improvement of Theme 3 Subtema 4 Learning Results Through Audio Visual Media in Class 1 Students of SDN Karangwangkal
}

\author{
Widya Kurniawati \\ SDN Karangwangkal \\ dy4endra@gmail.com
}

\section{Article History}

accepted $14 / 11 / 2020$

approved 21/11/2020

published 26/11/2020

\begin{abstract}
This research is a classroom action research (PTK) which consists of two cycles. This PTK has two cycles in one cycle, there are four stages, namely Plan, ACT and observer, reflect. The research subjects were grade I students of SDN Karangwangkal Banyumas, Central Java, with 26 students. Data collection techniques using test and non-test techniques. As for the assessment instrument using item items and observation of the scoring rubric. Analysis of the data used in the study included a comparative descriptive technique, namely a statistical technique by comparing the scores between cycles, the mean, the minimum score, the maximum, and the percentage. The results of the study that the use of audio-visual media can improve student learning outcomes in Theme 3 Sub-theme 4 Class 1 Night Activities of SDN Karangwangkal, this is evidenced by the learning outcomes in cycle I, namely 10 students out of 26 students or $38 \%$ who have not completed yet. students who complete as many as 16 students from 26 students or $62 \%$. In cycle II, there were 3 out of 26 students or $12 \%$ of the students who had not completed, while 23 students out of 26 students or $88 \%$ who had finished. This means that student learning outcomes increase from cycle I to cycle II. The conclusion of this study is that using audio-visual media can improve student learning outcomes in Theme 3 Sub-theme 4 Class 1 Night Activities of SDN Karangwangkal.
\end{abstract}

Keywords: learning media, audio visual, learning outcomes

\begin{abstract}
Abstrak
Penelitian ini merupakan penelitian tindakan kelas (PTK) yang terdiri dari dua siklus. PTK ini ada dua siklus dalam satu siklus ada empat tahapan yaitu Plan, ACT and observer, reflect. Subyek penelitian adalah siswa kelas I SDN Karangwangkal banyumas Jawa Tengah dengan jumlah siswa 26 anak. Teknik pengumpulan data dengan teknik tes dan non tes. Adapun instrumen penilaiannya menggunakan butir-butir soal dan pengamatan rubrik penilaian. Analisa data yang digunakan dalam penelitian meliputi yaitu teknik deskriptif komparatif yakni teknik statistik dengan membandingkan skor antar siklus, mean, skor minimal, maksimal, dan persentase. Hasil penelitian bahwa Penggunaan media audio visual dapat meningkatkan hasil belajar siswa pada Tema 3 Subtema 4 Kegiatan Malam Hari kelas 1 SDN Karangwangkal, hal ini dibuktikan dari hasil belajar pada siklus I yaitu siswa yang belum tuntas sebanyak 10 siswa dari 26 siswa atau 38\%, sedangkan siswa yang tuntas sebanyak 16 siswa dari 26 siswa atau $62 \%$. Pada siklus II, siswa yang belum tuntas sebanyak 3 siswa dari 26 siswa atau $12 \%$, sedangkan siswa yang tuntas sebanyak 23 siswa dari 26 siswa atau $88 \%$. Ini artinya hasil belajar siswa meningkat dari siklus I ke siklus II. Kesimpulan dari penelitian ini adalah menggunakan media audio visual dapat meningkatkan hasil belajar siswa pada Tema 3 Subtema 4 Kegiatan Malam Hari kelas 1 SDN Karangwangkal.
\end{abstract}

Kata kunci: media pembelajaran, audio visual, hasil belajar

Social, Humanities, and Education Studies (SHEs): Conference Series https://jurnal.uns.ac.id/shes

p-ISSN 2620-9284 e-ISSN 2620-9292 


\section{PENDAHULUAN}

Dalam UU RI No. 20 Tahun 2003 tentang Sistem Pendidikan Nasional, pasal 1 menjelaskan pendidikan adalah usaha sadar dan terencana untuk mewujudkan suasana belajar dan proses pembelajaran agar peserta didik secara aktif mengembangkan potensi dirinya untuk memiliki kekuatan spiritual keagamaan, pengendalian diri, kepribadian, kecerdasan, akhlak mulia, serta keterampilan yang diperlukan dirinya, masyarakat, bangsa dan negara.

Masa Pandemi Corona Virus 19 (covid 19) ini membuat proses pembelajaran yang biasanya dilaksanakan dengan tatap muka di depan kelas, tak dapat dilaksanakan lagi, hal ini karena adanya khawatiran makin menyebarnya covid19. Perlunya alternatif pembelajaran untuk menunjang kualitas pembelajaran yang baik demi keberlangsungan pendidikan putra dan putri bangsa Indonesia.

Penggunaan media pembelajaran berupa audio visual, memberikan warna berbeda dalam pembelajaran daring satu arah. Penggunaan media sosial WhatsApps adalah media pembelajaran yang banyak digunakan dan hampir semua kalangan bisa menggunakannya. Memadukan media sosial WhatsApps Grup dengan menampilkan media audio visual pada saat pembelajaran daring yang dilaksanakan pada WhatsApps Grup memudahkan guru menyampaikan materi dan siswa lebih tertarik melihatnya daripada hanya mendengarkan dan membaca chat tugas yang diberikan oleh guru.

Pada observasi awal sebelum penggunaan media audio visual hasil belajar siswa masih rendah pada pembelajaran tematik siswa kelas 1 SD Negeri Karangwangkal Jatilawang masih rendah yaitu dengan rata-rata kelas 60 dengan 7 siswa tuntas atau $27 \%$ dari seluruh siswa pada kelas 1 Tahun Pelajaran 2020/2021 di SDN Karangwangkal.

Perlunya inovasi dalam pembelajaran ini tentunya diharapkan dapat meningatkan kualitas pembelajaran siswa khususnya di masa adaptasi kebiasaan baru (New Normal) pada siswa kelas 1 Semester 1 Tahun Pelajaran 2020/2021 di SDN Karangwangkal, Kabupaten Banyumas, Jawa Tengah.

Berdasarkan hasil observasi aktivitas siswa yang dilakukan di kelas 1 Semester 1 Tahun Pelajaran 2020/2021 di SDN Karangwangkal, pada saat pembelajaran daring, yaitu siswa kurang berperan aktif. Pembelajaran di dominasi oleh guru. Sebagian siswa hanya mendengarkan penjelasan dari guru. Siswa kelas 1 Semester 1 Tahun Pelajaran 2020/2021 di SDN Karangwangkal.

Berdasarkan latar belakang yang telah diuraikan di atas, dengan mempertimbangkan solusi, peneliti menganggap bahwa penggunaan media audio visual dapat meningkatkan hasil belajar siswa kelas 1 SD Negeri Karangwangkal Tahun Pelajaran 2020/2021 sehingga perlu dilakukan penggunaan media tersebut ke dalam pembelajaran melalui penelitian yang berjudul "Peningkatan Hasil Belajar Tema 3 Subtema 4 Melalui Media Audio Visual pada Siswa Kelas 1 SDN Karangwangkal”.

\section{METODE}

Jenis penelitain ini adalah Penelitian Tindakan Kelas. Penelitian tindakan kelas merupakan penelitian yang dilakukan oleh guru di dalam kelasnya sendiri melalui refleksi diri, dengan tujuan untuk memperbaiki kinerjanya sebagai guru, sehingga hasil belajar siswa menjadi meningkat. Penelitian ini menerapkan 2 siklus.

Penelitian tindakan kelas (PTK) dilaksanakan pada siswa kelas 1 SDN Karangwangkal pada semester 1 Tahun Pelajaran 2020/2021. Subyek penelitian ini adalah siswa kelas 1 SDN Karangwangkal Jatilawang semester 1 tahun pelajaran 2020/2021, yang berjumlah 26 siswa, terdiri dari 9 orang siswa laki-laki dan 17 siswa perempuan.Tempat penelitian tindakan kelas di SDN Karangwangkal, Kabupaten Banyumas Provinsi Jawa Tengah. SDN Karangwangkal berada di Jl. Karangwangkal- 
Bantar, Kecamatan Jatilawang, kabupaten Banyumas. Waktu pelaksanaan pada bulan Oktober 2020.

1. Siklus 1

\section{HASIL DAN PEMBAHASAN}

a. Plan (Tahap Perencanaan)

Pada tahap ini peneliti melakukan perencanaan yang matang untuk mencapai tujuan pembelajaran. Peneliti menyiapkan dan menetapkan RPP beserta skenario tindakan mencakup langkah-langkah yang dilakukan peneliti dan peserta didik dalam kegiatan perbaikan pembelajaran. Skenario tindakan yang akan dilakukan oleh peneliti dan peserta didik dalam kegiatan perbaikan pembelajaran, yaitu :

1) Peneliti menyiapkan RPP, LKPD, lembar observasi dan evaluasi.

2) Peneliti menyiapkan media dan bahan ajar yaitu berupa power point, buku siswa dan buku guru

3) Peneliti dan observer mempersiapkan lembar observasi

b. ACT \& Observer (Implementasi Tindakan dan Observasi)

Proses implementasi tindakan, peneliti sebagai guru telah melaksanakan pembelajaran sesuai dengan RPP yang telah dirancang. Dalam pelaksanaan tindakan yang dilakukan peneliti sebagai berikut :

1) Peserta didik memulai pembelajaran melalui zoom.

2) Guru membuka pelajaran dan apersepsi

3) Peserta didik memperhatikan video (media audio visual) melalui power point yang share di zoom

4) Peserta didik bertanya dengan guru mengenai isi video

5) Perserta didik mengerjakan LKPD

Hasil observasi yang dilakukan oleh observer selama jalannya kegiatan pembelajaran dan mengamati hasil evaluasi pada akhir kegiatan siklus pertama belum berhasil karena siswa yang tuntas hanya 10 siswa dari 26 siswa. Siswa yang sudah tuntas baru mencapai $62 \%$.

c. Reflect (Refleksi)

Refleksi digunakan sebagai langkah untuk menganalisis kegiatan yang dilakukan pada siklus I. Kendala dalam pembelajaran siklus 1 adalah terkait miskonsepsi tentang kosakata yang berhubungan dengan kegiatan malam hari. Hasil dari siklus 1 ini akan diperbaiki dalam pembelajaran pada siklus 2 dengan cara menampilkan media berupa video yang lebih detail menjelaskan kosakata yang berhubungan dengan kegiatan malam hari.

\section{Siklus 2}

Pelaksanaan siklus II dilaksanakan karena siklus I belum berhasil mencapai indikator keberhasilan yang ditentukan. Kegiatan yang dilakukan pada siklus II merupakan penyempurnaan dari kelemahan atau kekurangan dari siklus I. Pelaksanaan siklus II dilaksanakan dengan langkah-langkah sama sebagai berikut :

a. Plan (Tahap Perencanaan)

Pada tahap ini peneliti melakukan perencanaan yang matang untuk mencapai tujuan pembelajaran. Peneliti menyiapkan dan menetapkan RPP beserta skenario tindakan mencakup langkah-langkah yang dilakukan peneliti dan peserta didik dalam kegiatan perbaikan pembelajaran. Skenario tindakan yang akan dilakukan oleh peneliti dan peserta didik dalam kegiatan perbaikan pembelajaran, yaitu :

1) Peneliti menyiapkan RPP, LKPD, lembar observasi dan evaluasi.

2) Peneliti menyiapkan media dan bahan ajar yaitu berupa power point, buku siswa dan buku guru

3) Peneliti dan observer mempersiapkan lembar observasi 
b. ACT \& Observer (Implementasi Tindakan dan Observasi)

Proses implementasi tindakan, peneliti sebagai guru telah melaksanakan pembelajaran sesuai dengan RPP yang telah dirancang. Dalam pelaksanaan tindakan yang dilakukan peneliti sebagai berikut :

1) Peserta didik memulai pembelajaran melalui zoom.

2) Guru membuka pelajaran dan apersepsi

3) Peserta didik memperhatikan video (media audio visual) melalui power point yang share di zoom

4) Peserta didik bertanya dengan guru mengenai isi video

5) Perserta didik mengerjakan LKPD

6) Peserta didik mengerjakan evaluasi

Hasil observasi yang dilakukan oleh observer selama jalannya kegiatan pembelajaran dan mengamati hasil evaluasi pada akhir kegiatan siklus kedua sudah berhasil karena siswa yang tuntas 23 siswa dari 26 siswa yaitu sebanyak $88 \%$.

c. Reflect (Refleksi)

Hasil belajar pada siklus II mengalami peningkatan dibandingkan dengan siklus I. Hasil evaluasi siklus I siswa yang tuntas mencapai $38 \%$, sedangkan pada hasil evaluasi siklus II siswa yang tuntas mencapai $88 \%$. Hal ini menunjukkan ada peningkatan hasil belajar siswa sebesar $40 \%$. Dari deskripsi di atas menunjukkan bahwa hasil rata-rata kelas meningkat pada siklus II, dengan kata lain dapat dikatakan berhasil dalam pembelajaran Tema 3 Subtema 4 karena siswa yang tuntas (KKM) sudah mencapai $88 \%$. Hasil dari penelitian ini tersaji pada tabel dan gambar sebagi berikut :

Tabel. 4.2 Hasil Belajar Siklus I-II

\begin{tabular}{cccc}
\hline Hasil Belajar & Pra siklus & Siklus I & Siklus II \\
\hline Tuntas & $27 \%$ & $62 \%$ & $88 \%$ \\
Tidak Tuntas & $73 \%$ & $38 \%$ & $12 \%$ \\
\hline
\end{tabular}

Berdasarkan tabel diatas terlihat bahwa terjadi peningkatan prosentase ketuntasan hasil belajar siswa dari siklus I sampai siklus II.

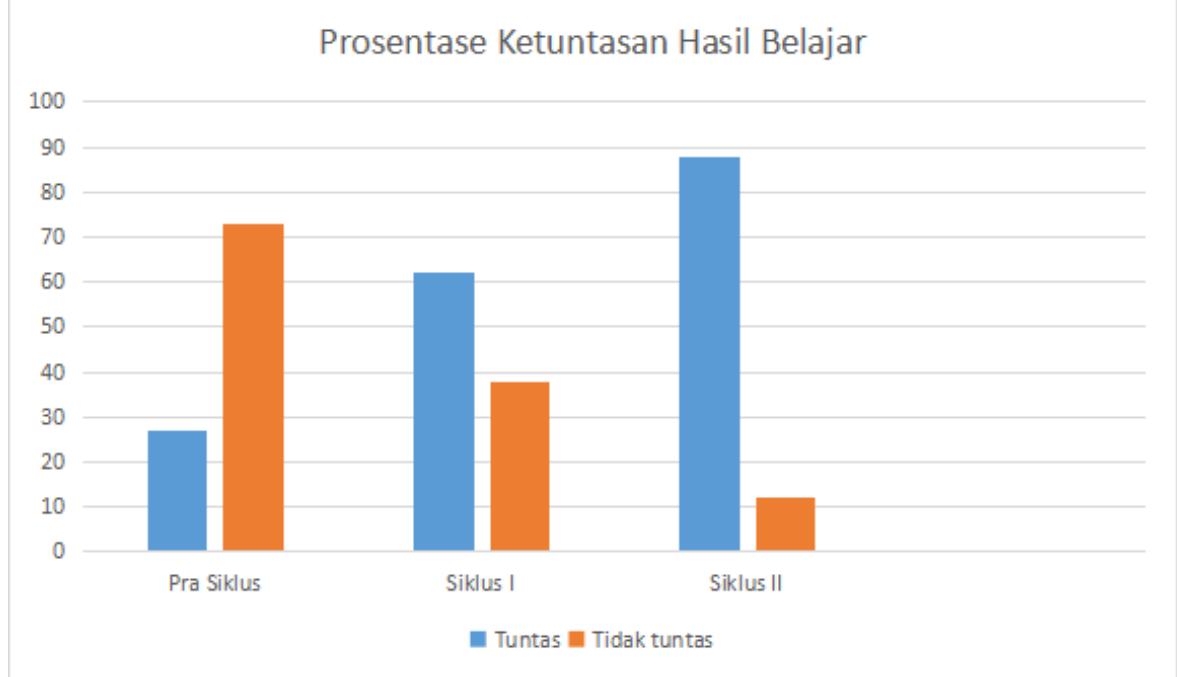

Gambar 1.1 Grafik Perbandingan Hasil Belajar Siklus I-II 


\section{SIMPULAN}

Penggunaan media audio visual dapat meningkatkan hasil belajar siswa pada Tema 3 Subtema 4 Kegiatan Malam Hari kelas 1 SDN Karangwangkal, hal ini dibuktikan dari hasil belajar pada siklus I yaitu siswa yang belum tuntas sebanyak 10 siswa dari 26 siswa atau 38\%, sedangkan siswa yang tuntas sebanyak 16 siswa dari 26 siswa atau 62\%. Pada siklus II, Pada kondisi awal sesuai dengan latar belakang penelitian, siswa yang belum tuntas sebanyak 7 siswa dari 26 siswa atau $27 \%$. Pada siklus II, siswa yang belum tuntas sebanyak 3 siswa dari 26 siswa atau $12 \%$, sedangkan siswa yang tuntas sebanyak 23 siswa dari 26 siswa atau $88 \%$. Ini artinya hasil belajar siswa meningkat dari siklus I ke siklus II.

Implikasi serta rekomendasi, hendaknya guru mengembangkan pembelajaran menggunakan media audio visual pada pelajaran yang lain

\section{DAFTAR PUSTAKA}

Aqib, Zainal, dkk. (2009). Penelitian Tindakan Kelas Untuk Guru SD, SLB dan TK. Bandung: Yrama Widya.

Ariyanto, V. (2016). Pengaruh Pembelajaran Audio Visual Terhadap Minat Belajar Siswa. Skripsi UNPAS Bandung.

Arsyad, Azhar. (2013). Media Pembelajaran. Jakarta: PT. Raja Grafindi Persada.

Rohani. (2013). Pengertian Media Audio Visual dalam Pembelajaran Makalah, Macam (Online).

Sanjaya , Wina. (2010). Penelitian Tindakan Kelas. Jakarta: Kencana. 